\title{
The Transitional Gabbroic Rocks in Bayah Geological Complex, Western part of Java, Indonesia, Inferred from XRF, ICP-MS, and Microprobe Analysis
}

\author{
Aton Patonah ${ }^{1}$, Haryadi Permana ${ }^{2,}$ Ildrem Syafri ${ }^{3}$ \\ ${ }^{1,3}$ Faculty of Geological Engineering, Padjadjaran University, Jatinangor, 45363, West Java, Indonesia \\ ${ }^{2}$ Research Center for Geotechnology LIPI, Jl Sangkuriang Bandung 40135, West Java, Indonesia \\ * Corresponding author : a.patonah@unpad.ac.id \\ Tel.: +62-812-2262-540 \\ Received: Jun 1, 2020; Accepted: Dec 24, 2021. \\ DOI: $10.25299 /$ jgeet.2021.6.4.7189

\begin{abstract}
Gabbro, is a fossil remnant of oceanic crust in western part of Java, found at Bayah Geological Complex (BGC) and Ciletuh Melange Complex (CMC), Indonesia. It has been studied by using petrographic, X-Ray Fluorescence (XRF), and inductively coupled plasma-mass spectrometry (ICPMS) and mineralogical (microprobe) analyses. Mineral and geochemical composition of these rocks provide important clues to their origins since the rocks have been deformed and gone through auto metamorphism, beside they contain the economic mineral and or rare earth elements (REE). Gabbroic rocks in these two areas generally shows phaneritic to porphyritic texture, granular texture. These rocks in CMC are dominated by plagioclase (oligoclase to albite), hornblende, pyroxene, partly altered to tremolite, actinolite, chlorite, epidote, and sericite; meanwhile those of BGC dominantly consist of plagioclase, pyroxene, hornblende, some present of chlorite, actinolite, epidote and biotite as secondary minerals. In multi-element diagrams, gabbroic rocks in CMC show strong negative $\mathrm{Sr}$ and $\mathrm{Zr}$, but positive $\mathrm{Nb}$ anomaly, while those of BGC show strong negative anomaly of $\mathrm{Nb}$ and $\mathrm{Zr}$. In addition, based on rare earth elements (REE) diagrams, gabbroic rocks in CMC show depleted of light rare earth elements (LREE) with negative Eu anomaly, while gabbro's in BGC show enrichment of LREE. These characteristics indicate that GBC's and CMC's gabbroic rocks came from different magma sources, one was formed by partial melting of depleted upper mantle reservoir while the other one was formed by partial melting of mantle wedge with active participation of subducted slab in an arc tectonic setting, suprasubduction zone which were formed at started Upper Cretaceous to Paleogene, and they had retrograde metamorphism to epidote amphibolite facies.
\end{abstract}

Keywords: Bayah geological complex (BGC), Ciletuh melange complex (CMC), Gabbro, REE, Arc tectonic setting, Retrograde metamorphism

\section{Introduction}

Gabbro is one component of an ophiolite sequence, the basaltic type, can be derived by partial melting from depleted upper mantle reservoir, heterogeneous reservoir (Zindler et al., 1984) or partial melting from oceanic crust which has relation with subduction process (Davidson, 1986). Different setting, such as arc-mechanism, has various compositions and complicated tectonic histories. According to Gill (1981), basaltic rocks contain $\mathrm{TiO}_{2}<1.3 \mathrm{wt} . \%$ formed in subduction zones (orogens), while basaltic rocks with $\mathrm{TiO}_{2}>1.3 \mathrm{wt} . \%$ are derived from non-orogenous environments, both oceanic and continental environments.

Gabbro, as part of ophiolite sequence Ciletuh Melange Complex (CMC), western part of java, is situated within the Indonesian archipelago at the Southern margin of Sundaland and the Eurasian Plate and is a part of the active Sundaland margin (Figure 1). This is recorded as a fragment Cretaceous oceanic crust, a complex zone that has recorded the convergent history between Indo-Australia dan Hindia Plate (Asikin 1974; Soekamto 1975; Thayib et al. 1977; Martodjojo et al. 1977; Suhaeli, 1977; Hamilton 1979; Schiller et al. 1991; Parkinson et al. 1998; Wakita, 2000; Patonah and Permana 2010; Satyana, 2014). Gabbro, together with other rocks (harzburgite, dunite, basalt, metamorphic rock and marine sediment) is overlain unconformity by Ciletuh Formation (Schiller et al. 1991). Some researchers have been concluded that the nature of oceanic crust (included gabbro) and the age of these rocks (Rosana et al.,
2015) the rock associated with Suprasubduction zone and MORB; Satyana, (2014) explained that gabbro as part of ophiolite CMC, is a product subduction of Late Cretaceous. For the age dating of gabbro's, Noeradi (1994) and Schiller et al. (1991), they said that as a component part of CMC, has the age of more less $55 \mathrm{Ma}$ or Middle Eocene. This implies that Gabbro in $\mathrm{CMC}$ was formed from Upper Cretaceous to Paleogene which associated with suprasubduction zone and MORB.

Recently, around $20 \mathrm{~km}$ northwest of CMC, western part of java, another gabbro has been found in Bayah Geological Complex (BGC) (Patonah and Permana 2018). The gabbro in BGC found boulders together with metapelitic rocks, it has not been found ultramafic yet. This becomes an interesting issue. Therefore, this study will compare the characteristic, the chemical analysis, and petrological data of gabbro in these two complexes to find the genetic and origin of gabbro corresponding to subduction - related. Moreover, this research will discuss the tectonic setting of these rocks.

\subsection{Geological Setting}

Geological setting of western part java is begun of mélange compex as product convergent at Upper Cretaceous - Early Paleogene Melange in Ciletuh Melange complex, is characterized by presenting of peridotite, dunite, serpentinite, gabbro, basalt, amphibolite, greenschist, and mica schist. This mélange is overlain unconformity by Ciletuh Formation in Ciletuh area, and Bayah Formation at Bayah area.

The study area form as part of CMC and BGC and is 
characterized by the occurrence of low - medium grade metamorphic rocks. In CMC, the field observation has been done in Cikopo, Cikepuh and Citisuk Rivers. In Cikepuh River, pegmatitic gabbro reveals with coarse - very coarse grained and shows auto-metamorphism and altered which are characterized by the presence of actinolite and chlorite consecutive (figure 2). This rock also experiences deformation which is indicated by brecciated. Serpentinized-Peridotite is found in the upstream of the rivers. It has deformed which is characterized by shearing zone $\mathrm{N} 280^{\circ} \mathrm{E} / 30^{\circ}$ and thrusted on the top of the sandstone with plane direction is $\mathrm{N} 235^{\circ} \mathrm{E} / 30^{\circ}$ or contacts with the shale from Ciletuh Formation with shearing zone is $\mathrm{N} 240^{\circ} \mathrm{E} / 35^{\circ}$.

Geological observation upstream of the rivers along Citisuk River (figure 2). Pillow lava has been exposed strongly altered in this area which is characterized by the presence of chlorite and carbonate minerals besides pyroxene and plagioclase. Tectonic contact between sedimentary rocks is found, and serpentinite is with plane direction of $\mathrm{N} 110^{\circ} \mathrm{E} / 70^{\circ}$. Serpentinite shows moderate to coarse grain and does not indicate deformation. The coarse grain gabbro's are found, some of the rocks show a mylonitic structure. In this location, outcrops of metamorphic rock are found with foliation plane $\mathrm{N} 300^{\circ} \mathrm{E} / 35^{\circ}$. They are covered by sedimentary rocks of the Ciletuh Formation. At the end of section, the pillow lava encloses unconformably above the Ciletuh Formation and complex ophiolite - metamorphic rock.

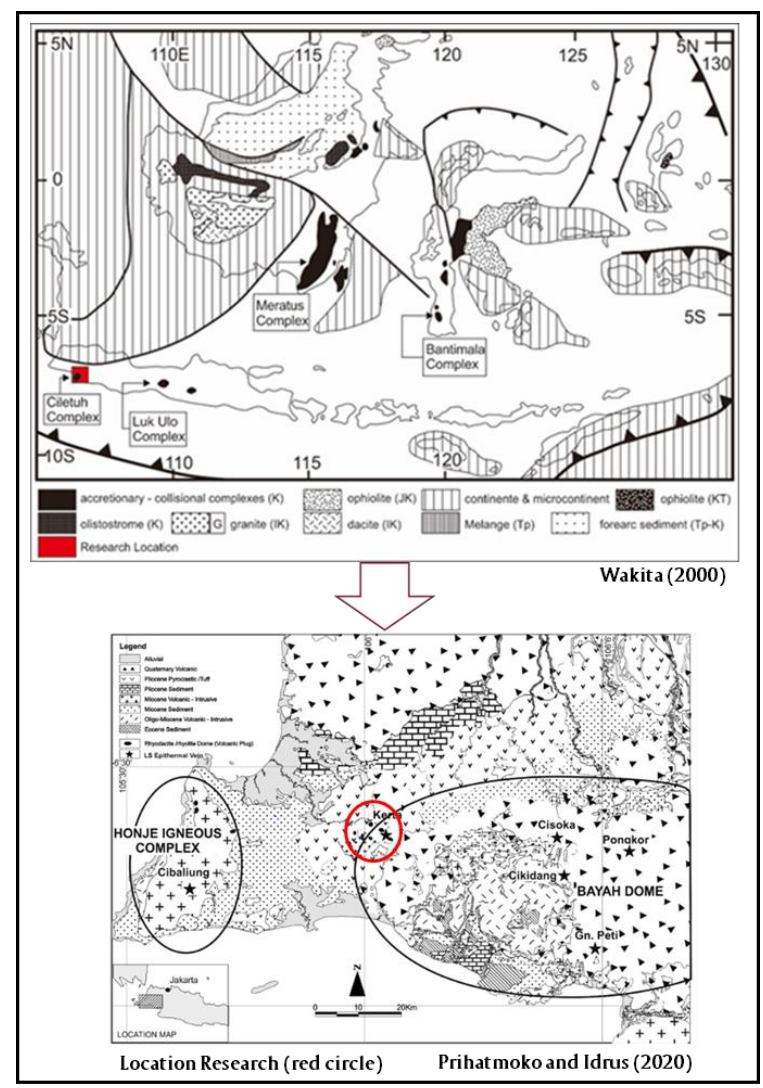

Fig 1. Ciletuh Melange Complex is one of major components of Cretaceous accretionary - collision complex of southern Sundaland (modified from Wakita, 2000); and Bayah Geological Complex is located at margin of Bayah Dome (Prihatmoko and Idrus, 2020).

In BGC, the field observation has been done in Cisanun and Cigaber Rivers. In Cisanun River (Figure 3), Gabbro generally reveals as boulders along this river, while the riverbank consists of porphyry andesite, diorite, mica schist and granodiorite (from downstream to upstream). Gabbro has dark grey color, phaneritic texture, some show oriented mineral, and some others show altered mineral, dominated by plagioclase, pyroxene, hornblende, and chlorite minerals. In another River (Cigaber River), gabbro's are also revealing as boulders, but showing more fine texture than those in Cisanun River. The Riverbank in the river is dominated by mica schist (figure 3 ).

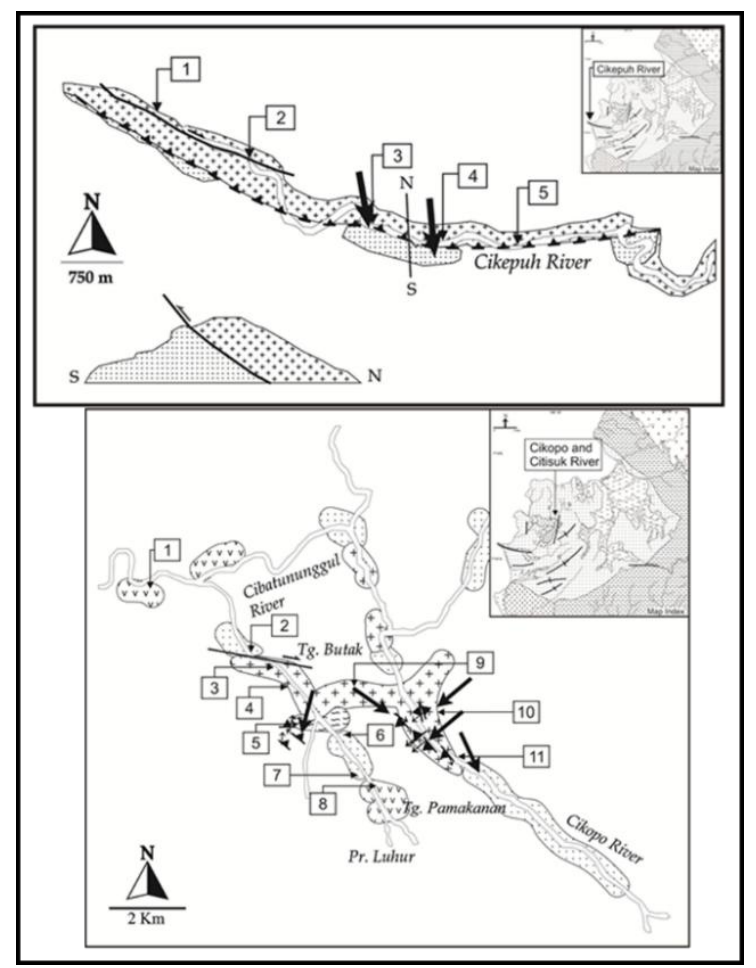

Fig 2. Field observation in Ciletuh Melange Complex (CMC).

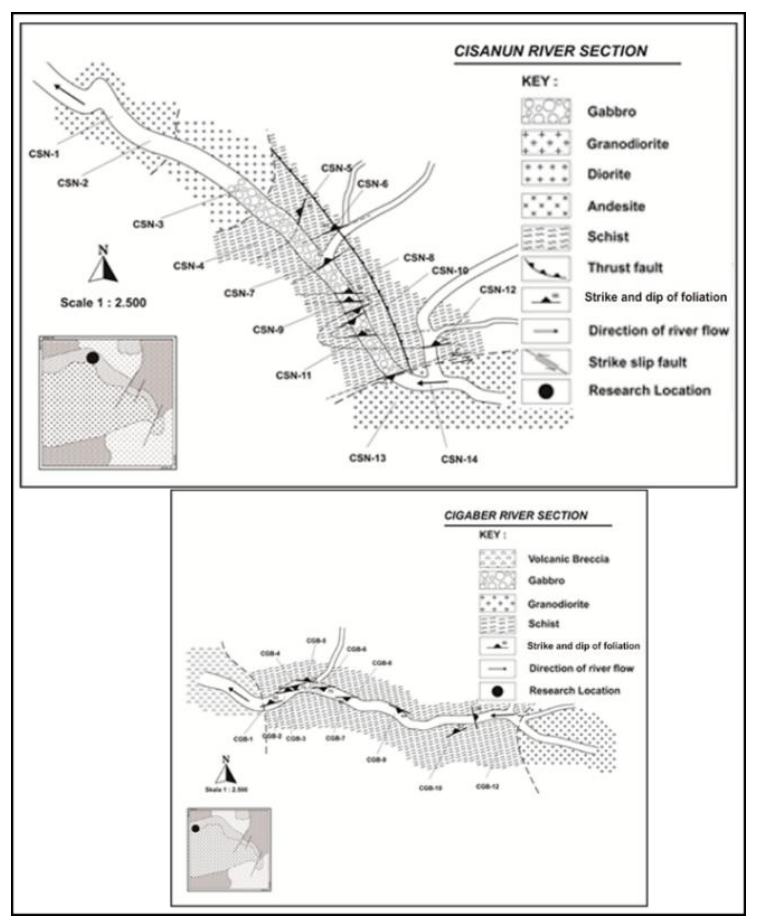

Fig 3. Field observation in Bayah Geological Complex (BGC).

\section{Material and Methods}

This paper will be focused on gabbro in those CMC and BGC. The material on this paper uses the rock samples from field observation conducted by 8 samples, 5 (five) samples from CMC and 3 (three) samples from BGC for this study (Table 1).

The methods that are used in this study are petrographic analysis, geochemical and microprobe analysis. The 
petrographic analysis has been done in laboratory of Petrology and Mineralogy, Faculty of Geological Engineering, University of Padjadjaran, and Research Center for Geotechnology LIPI, Bandung, Indonesia.

Table 1. Mineral composition of Gabbroic rocks in the research area.

\begin{tabular}{cccccccccc}
\hline $\begin{array}{c}\text { Sample } \\
\text { Code }\end{array}$ & \multicolumn{10}{c}{ Mineral Composition (\%) } \\
\cline { 2 - 10 } & plg & px & Amp & $\begin{array}{c}\text { Trem/ } \\
\text { Act }\end{array}$ & Ep & Cc & Chl & Clay & Op \\
\hline KP-2 & 65 & 0 & 20 & 7 & $<3$ & 0 & 3 & 0 & $<3$ \\
KO-10 & 45 & 8 & 20 & 0 & 8 & 7 & 7 & 0 & $<5$ \\
KO-12 & 75 & 0 & 15 & 0 & 3 & $<3$ & 0 & 0 & $<5$ \\
KO-15 & 50 & 0 & 25 & 0 & 7 & 8 & $<5$ & $<3$ & $<3$ \\
TK-16 & 65 & 7 & 20 & 0 & 2 & 3 & 0 & 0 & $<3$ \\
CGB 5 & 35 & 20 & 15 & 10 & 5 & 0 & 7 & 5 & 3 \\
CSN 4 & 35 & 25 & 7 & 8 & 5 & 0 & 8 & 7 & $<5$ \\
CSN 13 & 40 & 25 & 7 & 8 & 3 & 0 & 7 & 5 & 5 \\
\hline
\end{tabular}

Noted: $\mathrm{Plg}=$ plagioclase $; \mathrm{Px}=$ Pyroxene; $\mathrm{Amp}=$ Amphibole; Trem $/$ Act $=$ Tremolite $/$ Actinolite $; \mathrm{Ep}=$ Epidote $; \mathrm{Cc}=$ Calcite $; \mathrm{Chl}=$ Chlorite Serc $=$ Sericite $;$ Op $=$ Opaque

Geochemical analysis using X-Ray Fluorescence (XRF) and inductively coupled plasma-mass spectrometry ICP-MS is implemented on this study. These analyzes were done by INTERTEK, Jakarta in 2018. Whole rock major element abundances were determined by XRF with fused using lithium metaborate. Rare earth element and trace element were determined by Inductively-coupled plasma - mass spectrometry (ICP - MS) with a detection limit of 0.01 to 0.02 $\mathrm{ppm}$. The analytical errors for most elements were less than $2 \%$. Furthermore, mineral chemical analysis is used in this study. The samples were carried out at ORI, Tokyo by using JEOL super probe 733 electron Probe in 1999 through cooperation project between Research Center for Geotechnology LIPI, Bandung, Indonesia with Ocean Research Institute (ORI Tokyo). The samples analyzed by this method are samples from CMC (KP-2, KO-10, and KO-15). Data on mineral analysis calculations from microprobe are then recalculated based on 8 oxygen atoms in plagioclase; Amphibole is calculated on 23 oxygen atoms with an estimate of $\mathrm{Fe}^{2+} / \mathrm{Fe}^{3+}$ assuming $\sum 13$ cations. For the calculation of the iron as follows:

$\mathrm{FeO}=0.85 \times \mathrm{FeO}^{*}$ and $\mathrm{Fe}_{2} \mathrm{O}_{3}=0.15 \times \mathrm{FeO} * / 0.9$

The results of mineral probe analysis on amphibole are then grouped using the classification of Leake et al., 1997 with the following parameters:

1. Ca - Amphibole: $\mathrm{Ca}_{\mathrm{B}}<1.5 ;(\mathrm{Na}+\mathrm{K})_{\mathrm{A}}<0.5 . \mathrm{Ca}_{\mathrm{B}}<1,5 ;$

$(\mathrm{Na}+\mathrm{K})_{\mathrm{A}}<0,5$

2. Na - Ca Amphibole: $(\mathrm{Na}+\mathrm{K})_{\mathrm{A}}<0.5 ;\left(\mathrm{Ca}+\mathrm{Na} \mathrm{B}_{\mathrm{B}}\right)<1 ; 0.5<$

$\mathrm{Na}_{\mathrm{B}}<1.5$

$(\mathrm{Na}+\mathrm{K})_{\mathrm{A}}<0.5 ;\left(\mathrm{Ca}+\mathrm{Na} \mathrm{B}_{B}\right)<1 ; 0.5<\mathrm{Na}_{B}<1.5$.

3. Na - Amphibole: $\mathrm{NaB}<1.5 ;(\mathrm{Na}+\mathrm{K})_{\mathrm{A}}<0.5 ;\left(\mathrm{Mg}+\mathrm{Fe}^{2+}+\right.$ $\left.\mathrm{Mn}^{2+}\right)[2.5$.

$\mathrm{Na}_{\mathrm{B}}<1.5 ;(\mathrm{Na}+\mathrm{K})_{\mathrm{A}}<0.5 ;\left(\mathrm{Mg}+\mathrm{Fe}^{2+}+\mathrm{Mn}^{2+}\right)[2.5)$.

\section{Result and Discussion}

\subsection{Petrography}

Gabbro petrographic analysis in CMC is represented by 8 (eight) samples, while those of BGC are 3 (three) samples (Table 1). Based on petrographic analysis, most of the CMC's gabbros have altered and deformed, and they show phaneritic texture ( $2 \mathrm{~mm}$ to $8 \mathrm{~mm}$ ) and intergranular texture (KP 2). Major minerals are plagioclase, hornblende with minor amount of pyroxene and opaque mineral. Plagioclase has altered to chlorite, calcite, and epidote (KP 3), while most pyroxene alter to hornblende and actinolite - tremolite (figure 4A).

In KO-15 sample, gabbro shows lineation, some pyroxenes in this rock have altered to actinolite - tremolite and filled the fracture in plagioclase. Beside actinolite - tremolite, there is also the present of calcite, chlorite, and epidote as an alteration result of plagioclase. In $\mathrm{KO}-10$, there is fine aggregate chlorite (figure 4B) which is a product of plagioclase alteration, and present of epidote and hornblende (figure 4C).

In KO-12 sample, leucogabbro is dominated by feldspare (plagioclase), some hornblende (figure 4D). It has equigranular texture, medium grain, and lineation. Secondary minerals which compose this rock are epidote, calcite, and opaque minerals.

Evidence of deformation in gabbro is shown by bending of cleavage plane in pyroxene, fractured, elongated mineral, wavy extinction in almost minerals (plagioclase, hornblende, and pyroxene)

Gabbroic rocks which are exposed along Cisanun and Cigaber Rivers, BGC, show phaneritic to porphyritic texture, granular and intergrowth texture, medium to coarse grain, some minerals have lineation, fractured which is filled by chlorite and epidote minerals. The rocks are dominated by plagioclase (andesine to oligoclase) dan pyroxene and hornblende (figure 5C, 5D). Secondary minerals are actinolite, chlorite, epidote, and opaque minerals (figure 5A, 5B). Plagioclase has coarse grained, partly altered to chlorite and epidote. Pyroxene shows pale green to brownish color, prismatic texture, poor pleochroism, partly altered to hornblende, actinolite and chlorite (figure 5A, 5C). Hornblende has a green to brownish color, medium to strong pleochroism, and has cleavage one to two direction (figure 5A). Actinolite has a green color, fibrous to aggregate habit, medium pleochroism, occurring as replacement product of pyroxene. Chlorite has a green color, aggregate texture, poor to medium pleochroism. It occurs as an alteration result of pyroxene and plagioclase. Epidote has a brownish color, granular, high relief, high birefringence, as a result of alteration from plagioclase (figure 5E, 5F). Opaque mineral has a black color, fine to medium grain, and isotropic.

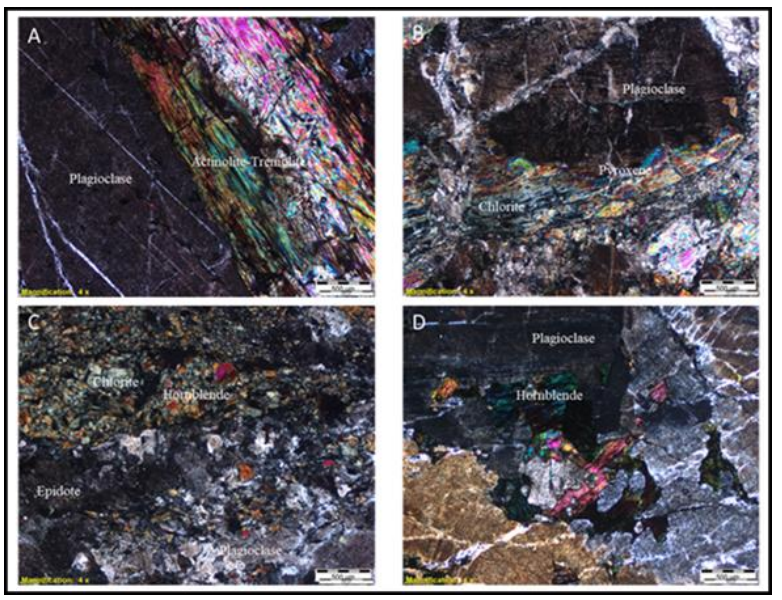

Fig 4. Photomicrograph of gabbro in Ciletuh Mélange Complex. (A) Pyroxene altered to tremolite-actinolite. (B) Chlorite is alteration mineral from Pyroxene. (C) Hornblende, epidote, and chlorite are present beside plagioclase and pyroxene; (D) some hornblende filled fracture in plagioclase.

\subsection{Geochemistry}

Here is the data of geochemistry of gabbro in CMC and BGC, western part of Java, Indonesia (Table 2).

Geochemical data (major elements) can be used to determine types of rock name, magmatic process, petrogenesis and tectonic setting. To determine type of rock, the data is plotted to total alkali vs silika diagram (TAS). The result is that the data falls in gabbro which is particularly similar to petrographic analysis (figure $6 a$ ) 
Table 2. Whole rock geochemical data of gabbro in western part of Java, Indonesia from various sources

\begin{tabular}{|c|c|c|c|c|c|}
\hline & CMC 2 & CMC 3 & CSN 4 & CGB 5 & CSN 13 \\
\hline \multicolumn{6}{|c|}{ Major oxides (wt\%) } \\
\hline $\mathrm{SiO}_{2}$ & 40.85 & 47.39 & 48.12 & 50.65 & 45.05 \\
\hline $\mathrm{TiO}_{2}$ & 4.74 & 4.55 & 1.04 & 1.16 & 0.78 \\
\hline $\mathrm{Al}_{2} \mathrm{O}_{3}$ & 9.14 & 11.92 & 12.45 & 20.35 & 13.78 \\
\hline $\mathrm{Fe}_{2} \mathrm{O}_{3}$ & 24.23 & 17.94 & 12.41 & 9.20 & 12.75 \\
\hline $\mathrm{MnO}$ & 0.38 & 0.26 & 0.24 & 0.03 & 0.44 \\
\hline $\mathrm{CaO}$ & 9.30 & 7.48 & 9.26 & 9.83 & 17.99 \\
\hline $\mathrm{MgO}$ & 4.47 & 4.74 & 12.68 & 3.30 & 6.65 \\
\hline $\mathrm{Na}_{2} \mathrm{O}$ & 2.66 & 4.10 & 1.44 & 3.14 & 0.83 \\
\hline $\mathrm{K}_{2} \mathrm{O}$ & 0.27 & 0.40 & 0.47 & 0.73 & 0.23 \\
\hline $\mathrm{P}_{2} \mathrm{O}_{5}$ & 1.49 & 0.22 & 0.26 & 0.26 & 0.26 \\
\hline $\mathrm{Cr}_{2} \mathrm{O}_{3}$ & 0.02 & 0.01 & 0.07 & 0.01 & 0.06 \\
\hline LOI & 1.70 & 1.10 & 1.65 & 1.12 & 0.65 \\
\hline Total & 99.25 & 100.11 & 100.09 & 99.77 & 99.47 \\
\hline \multicolumn{6}{|c|}{ Trace elements (ppm) } \\
\hline $\mathrm{V}$ & 275 & 393 & 252 & 305 & - \\
\hline $\mathrm{Cr}$ & 16 & 6 & 291 & 16 & - \\
\hline Co & 43 & 46 & 62 & 21 & - \\
\hline $\mathrm{Ni}$ & 23 & 24 & 174 & 16 & - \\
\hline $\mathrm{Ga}$ & 20.1 & 20.3 & 13.6 & 20.9 & - \\
\hline $\mathrm{Rb}$ & 2 & 3 & 9.7 & 18.6 & - \\
\hline $\mathrm{Sr}$ & 101 & 127 & 193 & 512 & - \\
\hline $\mathrm{Y}$ & 108 & 39.7 & 23.2 & 20.3 & - \\
\hline $\mathrm{Zr}$ & 98.4 & 104 & 34.6 & 11.9 & - \\
\hline $\mathrm{Nb}$ & 13.9 & 7.3 & 3.6 & 3.0 & - \\
\hline $\mathrm{Ba}$ & 23 & 24 & 78 & 141 & - \\
\hline $\mathrm{Pb}$ & $<1$ & 1 & 2 & 4 & - \\
\hline $\mathrm{Th}$ & 0.22 & 0.29 & 0.95 & 1.11 & - \\
\hline $\mathrm{U}$ & 0.008 & 0.07 & 0.20 & 0.17 & - \\
\hline
\end{tabular}

Rare earth elements (ppm)

\begin{tabular}{cccccc}
\hline $\mathrm{La}$ & 11.9 & 3.8 & 8.1 & 11.8 & - \\
$\mathrm{Ce}$ & 40.8 & 11.1 & 19.5 & 26.1 & - \\
$\mathrm{Pr}$ & 6.6 & 2.08 & 2.94 & 3.60 & - \\
$\mathrm{Nd}$ & 37 & 11.8 & 14.6 & 15.8 & - \\
$\mathrm{Sm}$ & 12.6 & 4.3 & 4 & 3.8 & - \\
$\mathrm{Eu}$ & 3 & 1.8 & 1.2 & 1.3 & - \\
$\mathrm{Gd}$ & 21.3 & 7.3 & 4.4 & 4.0 & - \\
$\mathrm{Tb}$ & 2.54 & 0.99 & 0.69 & 0.61 & - \\
$\mathrm{Dy}$ & 17.6 & 7.4 & 4.4 & 3.8 & - \\
$\mathrm{Ho}$ & 3.4 & 1.4 & 0.9 & 0.8 & - \\
$\mathrm{Er}$ & 9.5 & 4.1 & 2.5 & 2.1 & - \\
$\mathrm{Tm}$ & 1.2 & 0.6 & 0.3 & 0.3 & - \\
$\mathrm{Yb}$ & 8.1 & 4 & 2.3 & 1.9 & - \\
$\mathrm{Lu}$ & 1.22 & 0.62 & 0.37 & 0.28 & - \\
$(\mathrm{La} / \mathrm{Sm})_{\mathrm{N}}$ & 0.61 & 0.57 & 1.31 & 2.00 & - \\
$(\mathrm{Sm} / \mathrm{Yb})_{\mathrm{N}}$ & 1.73 & 1.19 & 1.93 & 2.22 & - \\
$(\mathrm{La} / \mathrm{Yb})_{\mathrm{N}}$ & 1.05 & 0.68 & 2.53 & 4.45 & \\
$(\mathrm{Na} / \mathrm{Nd})_{\mathrm{N}}$ & 0.63 & 0.63 & 1.09 & 1.47 & - \\
$(\mathrm{Tb} / \mathrm{Yb})_{\mathrm{N}}$ & 1.43 & 1.13 & 1.36 & 1.46 & - \\
\hline
\end{tabular}

\section{Noted:}

CMC 2, CMC 3 : gabbro in Ciletuh Melange Complexe (Rosana et al, 2015) CSN 4, CGB 5, CSN 13: gabbro in Bayah area

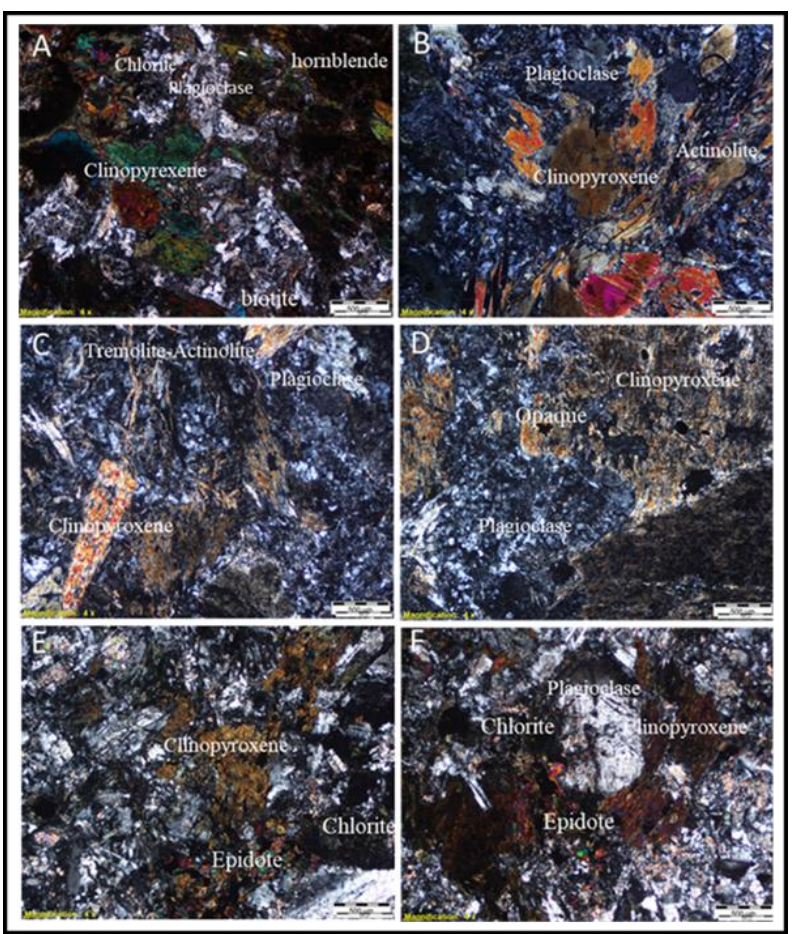

Fig 5. Photomicrograph under cross Nicol, gabbro's in Bayah area. (A and $\mathrm{B}$ ) present biotite, actinolite, hornblende and chlorite minerals beside clinopyroxene, and plagioclase; $(\mathrm{C}$ and $\mathrm{D})$ pyroxene is partly altered to tremolite - actinolite; ( $\mathrm{E}$ and $\mathrm{F}$ ) abundance of epidote and chlorite mineral replacing plagioclase.

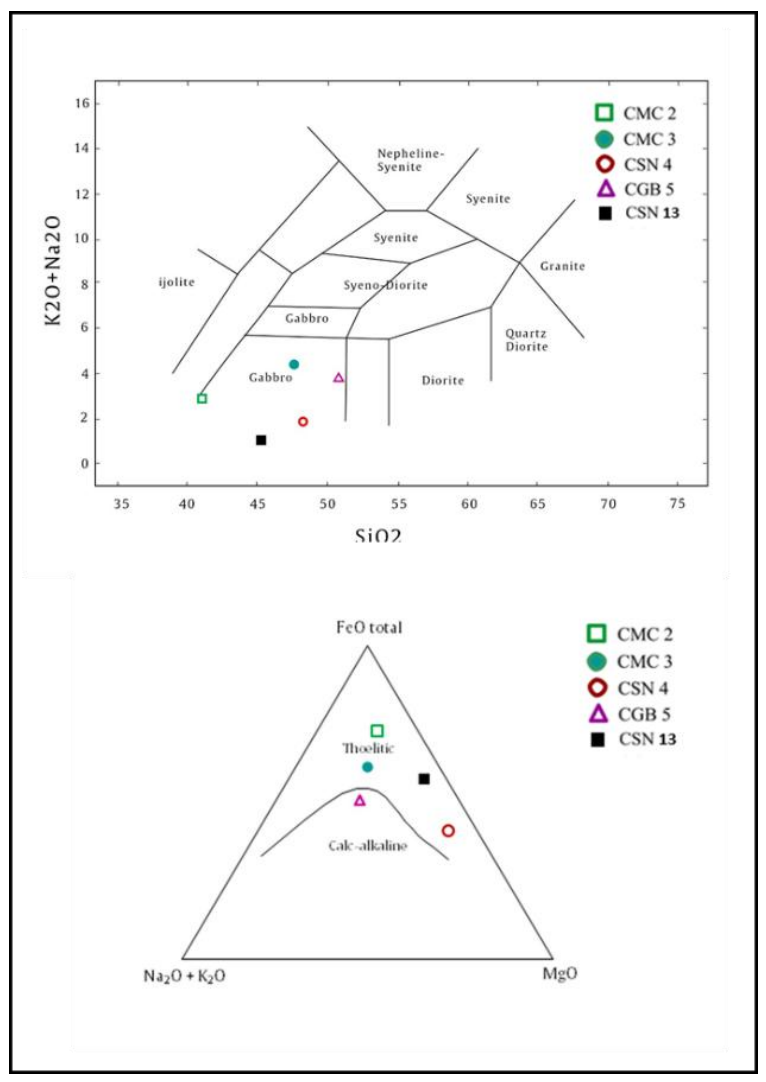

Fig 6. (a) Total alkali silicate (TAS) classification of gabbro in Western part of Java (after Cox et al., 1976); (b) AFM plot (Irvine and Baragar, 1971).

From major element composition, the gabbroic rocks from Western part of Java are characterized by low $\mathrm{SiO}_{2}$ content (40.85 - 50.65 wt.\%), wide range of $\mathrm{MgO}(3.30-12.68$ wt.\%), 
$\mathrm{Al}_{2} \mathrm{O}_{3}\left(9.14-18.15\right.$ wt. \%), and $\mathrm{Fe}_{2} \mathrm{O}_{3}(5.03-24.23$ wt. \%) and low $\mathrm{CaO}\left(7.48-11.24\right.$ wt.\%), except CSN 13 and low $\mathrm{TiO}_{2}$ (0.78 - 1.16 wt.\%) concentration, except in CMC (Table 2). Lower concentration of alkali $\left(\mathrm{Na}_{2} \mathrm{O}\right.$ and $\left.\mathrm{K}_{2} \mathrm{O}\right)$ (figure 7) possibility due to alteration process or cumulative nature of the rock (Dey et al., 2018; Kakar et al., 2013). It is supported by petrographic analysis that gabbroic rock in these two complexes has altered and retrograde metamorphism to epidote amphibolite, which is characterized by the presence of andesine to albite (plagioclase types), hornblende, actinolite and tremolite replacing pyroxene; epidote and chlorite replacing plagioclase. Measurement of pressure and temperature of gabbro in CMC based on the qualitative analysis (mineral assemblage; oligoclase - albite, hornblende, actinolite, epidote and chlorite), the rock has altered at the temperature of $300^{\circ} \mathrm{C}$ to $500^{\circ} \mathrm{C}$ and the pressure of $3 \mathrm{kbar}$ to $5 \mathrm{kbar}$ (Blundy and Holand 1990).

To determine magmatic affinity, the data is plotted in AFM diagram (Irvine and Baragar 1971). The result exhibits that gabbro fall in tholeitic to calc-alkaline affinity (figure $6 \mathrm{~b}$ ). $\mathrm{TiO}_{2}$ and $\mathrm{Al}_{2} \mathrm{O}_{3}$ contents of gabbro exhibit positive correlation with $\mathrm{MgO}$ (figure 7). It means that there is magmatic differentiation which is probably due to cumulate nature of gabbros.

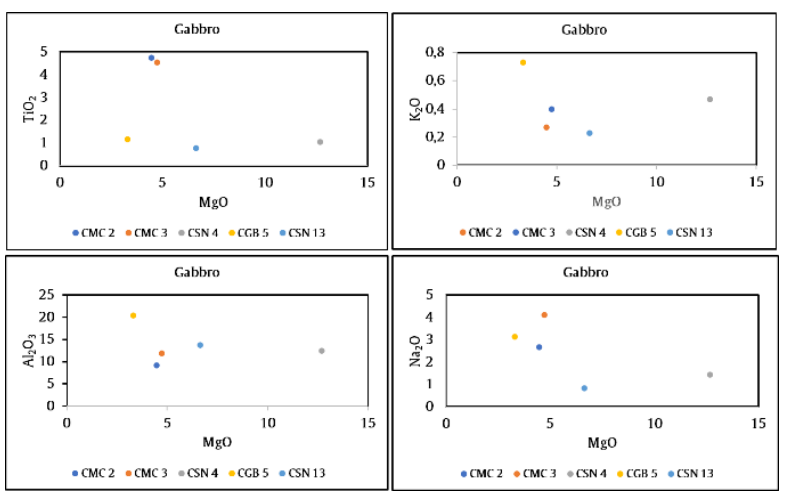

Fig 7. $\mathrm{MgO}$ vs selective major oxide plots for gabbro in Western part of Java.

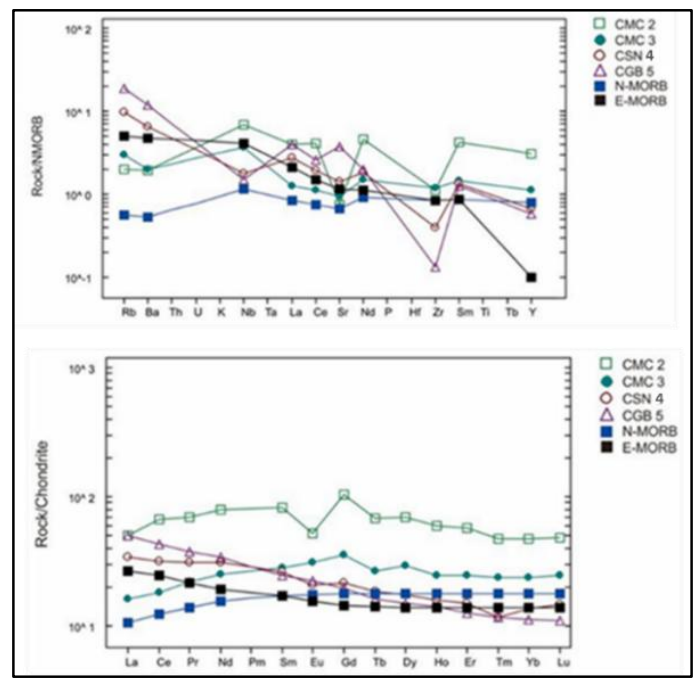

Fig 8. Normalizing values after Sun and McDonough (1989).

The result of trace element analysis shows variable $\mathrm{Nb}(3.6$ - 13.9 ppm), Rb (1.5 - 16.2 ppm), Sr (83.2 - $495 \mathrm{ppm})$, and Y $(19.5-108 \mathrm{ppm})$ (figure 8). The multielements patterns exhibit gabbro in BGC show enrichment of LILE, except for $\mathrm{Nb}$ and strong negative anomaly at $\mathrm{Zr}$ (figure 8 ). Meanhile, those of $\mathrm{CMC}$ exhibit positive anomaly at $\mathrm{Nb}, \mathrm{P}$ and $\mathrm{Sm}$, but negative anomaly at $\mathrm{Sr}$ and $\mathrm{Zr}$.
Furthermore, chondrite normalized rare earth element (REE) patterns of gabbroic rocks are shown in figure $8 \mathrm{~b}$. Samples of BGC shows enrichment of light REE [ $(\mathrm{La} / \mathrm{SM})_{\mathrm{N}}=$ $1.31-2$ ] and negative anomaly $\mathrm{Nb}$ conforming to E-MORB, while those of CMC show relatively depleted of LREE $\left[(\mathrm{La} / \mathrm{Sm})_{\mathrm{N}}=0.57-0.61\right]$ with negative $\mathrm{Eu}$ anomaly (see samples 2 in figure 8) conform to N-MORB.

\subsection{Mineral Chemistry}

Mineral chemistry analysis is carried out on 3 (three) gabbro samples from CMC, namely KO-10, KO-15 and KP-2. Minerals which are present in those rocks are amphibole and plagioclase.

Amphibole characterized by high content of $\mathrm{Si}, \mathrm{Mg}$ and lower content of $\mathrm{Al}^{\mathrm{i}}$. amphibole which composes gabbro generally varies, namely, magnesio-hornblende, actinolite, $\mathrm{Fe}-$ hornblende, and tremolite (figure 9).

Plagioclase in gabbro shows low anorthite $\left(\mathrm{An}_{1}-\mathrm{An}_{21}\right)$, namely albite to oligoclase (figure 9). These minerals are product of alteration from Ca-plagioclase. Potasium content generally shows low composition, lower than 0.09 atom per formula unite.

Based on the data, gabbroic rocks in CMC have retrograde to epidote amphibolite which are characterized by the presence of albite - oligoclase types, $\mathrm{Ca}$ - plagioclase altered to calcite, epidote and chlorite; while pyroxene alters to hornblende and tremolite - actinolte. In addition, these rocks have deformed which are signed by wavy extinction of almost mineral, fractured and folded. Indeed, It also happens to gabbro's BGC which has autometamorphism and retrograde to epidote amphibolite with the presence of hornblende, actinolite and chlorite minerals.

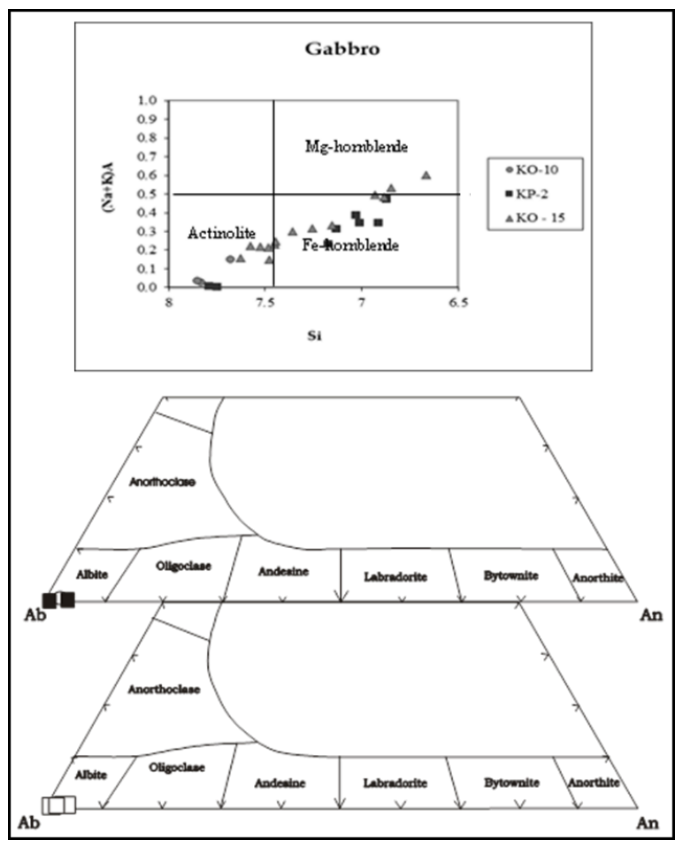

Fig 9. Type of amphibole and plagioclase (KO-10, KP-2, KO-15) in Gabbro of CMC (Leake et al., 1997).

\subsection{Discussion}

\subsubsection{Petrogenesis}

The geochemical characteristic of gabbroic rocks in western part of Java, Indonesia shows certain number of variations in terms of their major and trace element concentration due to possibility of different magma sources. It is generally considered as part of oceanic crust formed through magma derived from depleted mantle. Based on geochemical analysis, 
$\mathrm{TiO}_{2}$ content of gabbro in BGC is lower than $1.3 \%$ (Table 2) which means that these rocks are formed at subduction (orogen) process (Gill, 1981). This data is supported by high alumina $(13.78-20.35$ et $\%)$ which means that the rock associated with suprasubduction zone environments for the origin of magmas (Monnier et al. 1999). Furthermore, gabbroic rocks from BGC conform well with enrichment of light $\operatorname{REE}[(\mathrm{La} / \mathrm{Yb}) \mathrm{N}=2.53$ -4.45], and negative anomaly at $\mathrm{Nb}$ and $\mathrm{Zr}$ which are related by arc related setting or subduction - related magma (Fawzy and El-ela, 1997) (figure 8). It indicates that source of magmas is formed by partial melting of mantle wedge with active participation of subducted slab in an arc tectonic setting (Dey et al., 2018) and possibility of relation with suprasubduction ophiolite (Wallin and Metcalf, 1998). Depletion of HREE pattern in these rocks $\left[(\mathrm{Tb} / \mathrm{Yb})_{\mathrm{N}}=1.36-1.46\right]$ suggest that it is subduction-related magma derived at least in part from mantle - wedge and parent magma was of relatively primitive mantle source (Fawzy and El-ela, 1997). These characteristics indicate that the rocks are associated with orogenic type (Wilson, 1989).

Gabbroic rocks in CMC are different character from those of $\mathrm{BGC} \mathrm{TiO}_{2}$ content in $\mathrm{CMC}^{\prime}$ 'gabbros show higher than 1.3 wt.\% which is interpeted as non orogen association in origin.

Furthermore, the spidergrams of the CMC's gabbro (figure 8) conform well with N-MORB which is interpreted that the rocks are derived by partial melting of isotopically faily homogeneous, well mixed and depleted upper mantle reservoir (Zindler et al., 1984). Moreover, the REE patterns in these rocks show negative $\mathrm{Eu}$ anomaly which means that the rock has fractionally crystallized plagioclase or may have been in equilibrium with a plagioclase - bearing mantle sources (Wilson, 1989).

Based on the REE pattern of these rocks, there are two possibilities of two types of source magma in western part of Java, Indonesia. Firstly, one is formed by partial melting of depleted upper mantle reservoir, and the other one is formed by partial melting of mantle wedge with active participation of subducted slab in an arc tectonic setting.

\subsubsection{Tectonic Implication}

To understand tectonic setting for the emplacement of different magma type of Western part of Java, Indonesia, different tectonic discrimination diagrams are used. the $\mathrm{Ce} / \mathrm{Y}$ vs $(\mathrm{La} / \mathrm{Yb})$ n diagram (Saunders et al., 1988), gabbroic rocks fall in an around N MORB and EMORB (figure 10), suggesting their contribution possibly from depleted and enriched mantle to near crust respectively. Furthermore, based on $\mathrm{Cr}$ vs $\mathrm{Y}$ diagram (Pearce, 1982), Gabbros fall in Island Arc Tholeite (IAT) and in overlapped by Within Plate Basalt and MORB (figure 11). This implies that the gabbros in western part of Java are formed at MORB to arc environment (suprasubduction zone) tectonic settings.

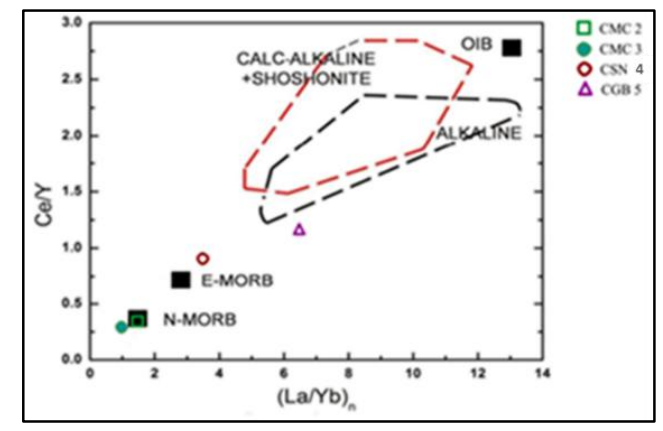

Fig 10. Source magma characterization for gabbro in western part of Java. (a) $\mathrm{Th} / \mathrm{Yb}$ vs Nb/Yb plot (after Pearce, 2008)); (b) Ce/Y vs $(\mathrm{La} / \mathrm{Yb}) n$ plot, Modern N - MORB and E MORB points (Sun and McDonough, 1989).

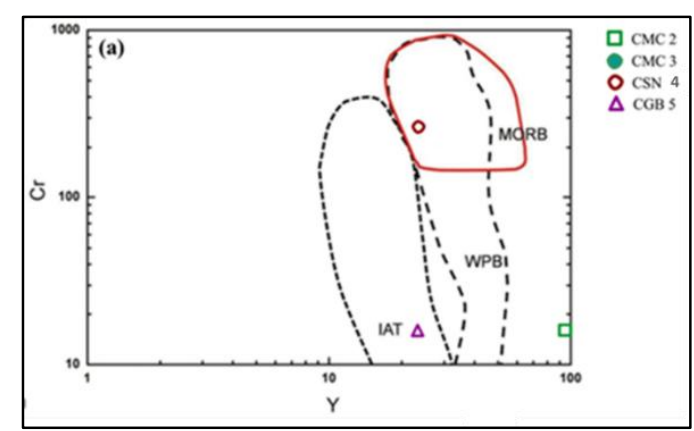

Fig 11. Tectonic discrimination diagram for gabbro in Western part of Java. (a) Cr vs Y plot (Pearce, 1982)

\section{Conclusion}

Petrological study of gabbroic rock from Western part of Java exhibits that there are different characteristics between $\mathrm{CMC}$ and GBC. Gabbro in CMC is more various, more altered, and intensely deformed than those of BGC. In BGC, there are some gabbro which has been influenced by hydrothermal process which is characterized by present epidote and chlorite, also vein which is filled with epidote and chlorite minerals. These cases are supported by geochemical analysis. Based on geochemical characteristic, lower $\mathrm{TiO}_{2}(<1.3 \%)$ in $\mathrm{BGC}$ included orogenic process in origin, meanwhile those of CMC is non orogenic process. Furthermore, gabbro rocks show enriched LREE in BGC with negative anomaly at $\mathrm{Nb}$ and $\mathrm{Zr}$, meanwhile those of CMC depleted to LREE with negative Eu, $\mathrm{Sr}$ and $\mathrm{Zr}$ anomaly. The characteristic of the composition is genetically related to MORB (CMC) to an arc (BGC) related tectonic setting, supra subduction zone, where the gabbroic rocks in BGC are predicted to be transitional opening continental margin products. Forming gabbro in western part of Java is predicted to start being formed at Upper Cretaceous to Paleogene (Middle Eocene). Retrograde metamorphism happens to these rocks to epidote amphibolite, which is characterized by the presence of hornblende, oligoclase to albite, actinolite - tremolite, chlorite and epidote minerals.

\section{Acknowledgements}

The authors would like to thank the Director of Geotechnology LIPI who has given me a chance to conduct a collaboration research, and the Director of Research and Community Service and Innovation of UNPAD who has contributed to the research so that it can be smoothly completed.

\section{References}

Asikin, S., 1974. Evolusi geologi Jawa Tengah dan sekitarnya ditinjau dari segi tektonik dunia yang baru. ITB.

Blundy, J.D., Holand, T.J.B., 1990. Calcic amphibole equlibria and a new amphibole - plagioclase geothermometer. Massachusetts Institute of Technology, USA, pp. 208213.

Cox, K.G., Hawkesworth, C.J., O’Nions, R.K., Appleton, J.D., 1976. Isotopic evidence for the derivation of some Roman region volcanics from anomalously enriched mantle. Contrib. to Mineral. Petrol. 56, pp.173-180. https://doi.org/10.1007/BF00399602

Davidson, J., 1986. Isotopic and trace element constraint on the petrogenesis of subduction related lavas from Martinique, Lesser Antilles. J. Geophys. Res 91, pp. 5943-62.

Dey, A., Hussain, M.F., Barman, M.N., 2018. Geoscience frontiers geochemical characteristics of mafic and ultramafic rocks from the Naga Hills Ophiolite, India : Implications for petrogenesis. Geosci. Front. 9, pp. 517529. https://doi.org/10.1016/j.gsf.2017.05.006 
El-ela, Abu., Fauzy. F., 1997. Geochemistry of an island-arc plutonic suite: Wadi Dabr intrusive complex , Eastern Desert, Egypt 24, pp.473-496.

Gill, J.B., 1981. Orogenic andesites and plate tectonics. Springler-Verlag.358p

Hamilton, W., 1979. Tectonics of the Indonesian Region, US Geological Survey Professional Paper 1078. Washington. https://doi.org/10.1016/00036870(73)90259-7

Irvine, T.., Baragar, W.R.A., 1971. A Guide to the chemical classification of the common volcanic rocks. Can. J. Earth Sci. 8, pp. 523-548.

Kakar, I.., Khalid, M., Khan, M., Kasi, A.., Manan, R.., 2013. Petrology and geochemistry of gabbros from the Muslim Bagh Ophiolite; Implications for their petrogenesis and tectonic setting. J. Himal. Earth Sci. 46, pp. 19-30.

Leake, B.E., Wooley, A.R., Arps, C.E.S., Birch, W.D., Gilbert, M.C., Grice, J.D., Hawthorne, F.C., Kato, A., Laird, J., Mandarino, J., 1997. Nomenclature of amphiboles. Rep. subcommitee amphiboles Int. Mineral. Assoc. Comm. new Mineral and mineral names, pp. 295-321.

Martodjojo, A., Suparka, S., Hadiwisastra, S., 1977. Status Formasi Ciletuh dalam evolusi Jawa Barat, in: Proc. Ikatan Ahli Geologi Indonesia, pp. 1-13.

Monnier, C., Girardeau, J., Pubellier, M., Polvfi, M., Permana, H., Bellon, H., 1999. Petrology and geochemistry of the Cyclops ophiolites .( Irian Jaya , East Indonesia ): consequences for the Cenozoic evolution of the north Australian margin, pp. 1-28.

Noeradi, D., 1994. Contribution A L' etude geologique D'une partie occidentale de L'Ile de Java - Indonisie. Stratigraphie, analyse structurale et etude quantitative de la subsidence des bassins sedimentaires Tertiares. approache de la geodynamique D'une marge continentale.

Parkinson, C.., Miyazaki, K., Wakita, K., Barber, A.., Carswell, D.., 1998. An overview and tectonic synthesis of the PreTertiary very-high-pressure metamorphic and associated rocks of Java, Sulawesi and Kalimantan, Indonesia. Isl. Arc 7, pp. 184-200.

Patonah, A., Permana, H., 2018. Basement characteristic Western Part of Java, Indonesia; case study in Bayah Area, Banten Province. Int. J. Adv. Sci. Eng. Inf. Technol. $8, \quad$ pp. 2135-2141. https://doi.org/10.18517/ijaseit.8.5.5907

Patonah, A., Permana, H., 2010. Petrologi amfibolit komplek melange Ciletuh, Jawa Barat. Bul. Sci. Contrib. 8, pp. 69-77.

Pearce, J.., 1982. Trace Element characteristics of lavas from destructive plate boundaries. In: Thorpe, R.S. (Ed), Andesites.

Pearce, J.A., 2008. Geochemical fingerprinting of oceanic basalts with applications to ophiolite classification and the search for Archean oceanic crust. Lithos 100, pp. 1448. https://doi.org/10.1016/j.lithos.2007.06.016

Prihatmoko, S., Idrus, A., 2020. Low-sulfidation epithermal gold deposits in Java, Indonesia: Characteristics and linkage to the volcano-tectonic setting. Ore Geol. Rev.

121 , 103490.

https://doi.org/10.1016/j.oregeorev.2020.103490

Rosana, M.F., Yuningsih, E.T., Saragih, K.D., Ikhram, R., Ardiansyah, N., 2015. Petrologi Batuan Ofiolit Daerah Sodongparat, Kawasan Ciletuh, Sukabumi. Bull. Sci. Contrib. 13, pp. 221-230.

Satyana, A. H, 2014. New consideration on the Crestaceous subduction zone of Ciletuh-Luk Ulo-Bayat-Meratus: Implications for southeast sundaland petroleum geology, in: Proceedings, Indonesian Petroleum Association, Thirty-Eight Annual Convention \& Exhibition, pp. 1-41.

Satyana, Awang H, 2014. Tectonic evolution of Cretaceous convergence of Southeast Sundaland: A new synthesis and its implications on petroleum geology. Ikat. Ahli Geol. Indonesia, pp. 1-28.

Saunders, A.., Norry, M.., Tarney, J., 1988. Origin of MORB and chemically-depleted mantle reservoirs: trace element constraints. J. Petrol. Special Li, pp. 415-445.

Schiller, D.M., Garrard, R.A., Prasetyo, L., 1991. Eocene Submarine Fan Sedimentation in Southwest Java, in: Proceeding Indonesian Petroleum Association, pp. 125181

Slovenec, D., Lugović, B., 2008. Amphibole gabbroic rocks from the Mt Medvednica ophiolite mélange ( NW Croatia ): geochemistry and tectonic setting, pp. 277 293.

Soekamto, R., 1975. Geological Map of the Jampang and Balekambang Quadrangles, Java, Scale 1: 100,000. Bandung.

Sun, S.S., McDonough, W.F., 1989. Chemical and isotopic systematics of oceanic basalts: Implications for mantle composition and processes. Geol. Soc. Spec. Publ. 42, pp. https://doi.org/10.1144/GSL.SP.1989.042.01.19

Thayib, E., L, S.E., Siswoyo, S, P., 1977. The Status of the melange complex in Ciletuh area, Southwest Java., in: Proc.of the 6th IPA Convention, pp. 1-8.

Wakita, K., 2000. Cretaceous accretionary-collision complexes in central Indonesia. J. Asian Earth Sci. 18, pp. 739-749. https://doi.org/10.1016/S1367-9120(00)00020-1

Wallin, E.T., Metcalf, R. V., 1998. Supra-subduction zone ophiolite formed in an extensional forearc: Trinity terrane, Klamath Mountains, California. J. Geol. 106, pp. 591-608. https://doi.org/10.1086/516044

Wilson, M., 1989. Igneous Petrogenesis. A global tectonic approach. Unwin Hyman, London, 566p.

Zindler, A., H, S., R, B., 1984. Isotope and trace element geochemistry of young Pacific seamounts: implications for the scale of upper mantle heterogenety. Earth Planet 70 , pp. 175-95.

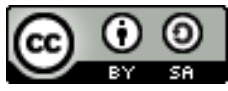

(C) 2021 Journal of Geoscience, Engineering, Environment and Technology. All rights reserved. This is an open access article distributed under the terms of the CC BY-SA License (http://creativecommons.org/licenses/by-sa/4.0/). 